\title{
When Socialism Meets Market Capitalism: challenges for privatizing and marketizing education in China and Vietnam
}

\author{
KA HO MOK \\ The University of Hong Kong
}

\begin{abstract}
China and Vietnam have experienced drastic social, economic and political changes, especially when these two socialist regimes have started economic reforms in the last few decades. In order to create more opportunities for higher education with limited national resources, both Chinese and Vietnamese governments have adopted strategies along the lines of marketization and privatization to reform their higher education systems. The major objective of this article is to critically examine how the market transition taking place in China and Vietnam has led to changes in education governance, particularly examine how these two governments have approached the challenges of global capitalism by transforming the socialist education model into a more market-oriented one. This article also discusses the major challenges and policy implications when education is increasingly privatized and marketized in China and Vietnam.
\end{abstract}

\section{Introduction}

Both China and Vietnam have experienced significant social and economic changes since the adoption of market-oriented reforms to transform their economies in the late 1970s in China and in the late 1980s in Vietnam. Since the late 1970s, economic reform in China has significantly transformed the society not only in the economic aspect but also in social and political dimensions. Embracing the market economy has made China possibly the largest manufacturing powerhouse globally. With consistent and steady GDP growth in the last two decades, China has become one of the major economic powers in Asia (So, 2003; Saich, 2004). After its accession to the World Trade Organization (WTO) in 2001, China has begun to integrate with the global market. More importantly, China's proactive approach in establishing free trade zones with neighbouring countries has enhanced its geopolitical influences in Asia (Cai, 2005; Liu, 2005).

Similar to China, Vietnam has undergone a transition from state socialism to market socialism. The adoption of the policy of doi moi (renovation) in 1986 is usually considered as the beginning of the economic reform in Vietnam. However, the geopolitical events since 1989 are probably the real breakthrough in Vietnam's socio-economic transition as those events have dissipated the salience of Cold War concerns in Asia and therefore have reinserted Vietnam into regional and world markets. These changes have greatly speeded up Vietnam's market transition and have consequently pushed the Communist Party to reconstitute state-society relations in Vietnam (London, 2003).

This article sets out in the wider socio-economic contexts briefly outlined above to examine how the market transition taking place in China and Vietnam has led to changes in education governance, with particular reference to a discussion of how China and Vietnam approach the 
challenges of global capitalism by transforming the socialist education model into a more marketoriented one. After discussing changes in education governance, the article will examine major challenges and policy implications when education is increasingly privatized and marketized in these Asian countries.

\section{Changes in Social Policy Philosophy: impacts on education policy}

The adherence to market principles and practices has affected not only the economic sphere but also the way social welfare and social policy is managed. Since the late 1970s, the principle of full subsidization in social policy during the Mao era has been abandoned, and the implementation of policies in line with decentralization and marketization has altered the way social policy/social welfare is managed in China. Social welfare and social services used to be dominated by state provision and financing, but are now increasingly run on market principles (Guan, 2001; Wong \& Flynn, 2001; Mok, 2005). In order to cut welfare burdens and promote economic efficiency of the state sector, social policy provision, social security and social protection have experienced significant restructuring. Nowadays, Chinese citizens have to become self-reliant and they need to pay for the major social services such as health, education and housing (Wong \& Flynn, 2001; Wong et al, 2004). As Cook (2002) has rightly suggested, Chinese citizens nowadays no longer enjoy the 'iron rice bowl' and 'social security', especially when major social responsibilities have gone to individuals and families. Hence, it is not surprising to hear popular complaints among Chinese citizens about the three new mountains being left to them by the state, namely, bearing more financial burdens for education, health and housing ( $\mathrm{Zhu}, 2005)$.

In the new socialist market economy context, the old way of 'centralized governance' in education has been rendered inappropriate (Yang, 2002). Acknowledging that over-centralization and stringent rules would kill the initiatives and enthusiasm of local educational institutions, the Chinese Communist Party (CCP) called for resolute steps to streamline administration, and devolve powers to units at lower levels so as to allow them more flexibility to run education. As early as 1985, the CCP issued the Decision of the Central Committee of the Chinese Communist Party of China on the Reform of the Educational System which marked the beginning of a process of educational reform and gradually aligned the educational system with the newly emerging market economy. The documents called for the devolution of power to lower levels of government and a reduction in the rigid governmental controls over schools (CCCCP, 1985). Since then, the state has started to diversify educational services, allowing and encouraging the non-state sector to establish and run educational institutions. Meanwhile, the state has deliberately devolved responsibility and power to local governments, local communities and other non-state actors by providing a necessary framework for educational development (Hawkins, 2000; Ngok \& Chan, 2003). The Outline for Reform and Development of Education in China issued in 1993 restated the reduction of centralization and government control in general as the long-term goals of reform (CCCCP, 1993). The government began to play the role of 'macro-management through legislation, allocation of funding, planning, information service, policy guidance and essential administration'. The retreat of the central state provided space for local states as well as non-state actors to take more responsibilities for education provision, financing and regulation. Therefore, non-state bodies started to provide education in the formal education sector, thereby leading to the emergence of minban (people-run) schools and colleges (Mok, 2007).

While maintaining its control over its socialist ideology, the Vietnamese government has effectively shifted an increasing burden of the costs of social services from the state onto individual households. Similar to China, the Vietnamese government has decided to engage with the global economy by gaining membership of the WTO. Honouring the regulations of the WTO, the Education Law issued in 2005 in Vietnam no longer prohibits the commercialization of educational activities. Following the principles of the General Agreement on Trades and Services (GATS), the Vietnamese government has begun to regard higher education as a commodity; thereby a spontaneous and immature education market has begun to emerge (Pham, 2006). In fact, education provision and financing began to change when the policy of 'socialization' ( $x a$ hoi hoa) was adopted in the early 1990s. Central to the socialization policy is the shifting of costs from the state onto society in Vietnam; thereby social service provision is no longer purely a welfare entitlement but 
citizens have to make financial contributions when making use of social services. Similar to China, the Vietnamese government has realized that depending upon the state's subsidies would never satisfy people's pressing educational needs, and diversifying educational finances and proliferating educational providers has therefore become an increasing popular trend (Banh, 2006). It is against such a policy context that the Vietnamese government began to allow the emergence of 'semipublic' and 'non-state' provision of social services, and meanwhile it undertook cost-recovery and cost-reduction measures in various social services. Today, the principle of cost-sharing has been deeply embedded in different social policy areas and its impacts have consolidated the emergence of a hybrid welfare regime in Vietnam (London, 2003; Bélanger \& Liu, 2004).

Given the new challenges generated from rapid socio-economic developments in the market transition, the socialist model of education, which is characterized by centralized power, bureaucracy and subsidies, is no longer able to meet the requirements for the new development (Nguyen \& Sloper, 1995). Realizing the difficulty of separating higher education development from the economic development of the country, the Vietnamese government has therefore changed its governing philosophy of higher education (Overland, 2006). Decree No. 90/CP issued in 1993 stipulated that all people have the right to pursue higher education, and thus led to a tide of massification of higher education in the country. For example, total higher education enrolment grew from 162,000 in 1993 to 1.3 million in 2003, while the number of higher education institutions has grown from 120 in the early 1990s to 224 in 2004 (Institute of International Education [IIE], 2005 , p. 5; Hayden \& Lam, 2007, p. 74). Following up the massification of education, the Vietnamese government has sought the diversification of educational provision because it cannot solely bear the financial burden of an expanded tertiary education. Since the establishment of the first non-public university in 1988, non-public higher education has been continuously increasing its role and function in Vietnam's higher education system (Ngo, 2006, pp. 243-244). The entry to the WTO has further liberated the education market in Vietnam and private higher education is expanding in the country.

Reshuffling the monopolistic role of the state in educational provision, and reforms in the educational structure in China and Vietnam have made education a mixed economy of private and public consumption (Cheng, 1995; London, 2003). Both communist authorities have begun to realize that education is a sort of investment and an important structural component of socioeconomic infrastructure in the knowledge-based economy. Realizing that depending upon the state alone would never satisfy the strong demands for education in the new socio-economic settings, the proliferation of education providers and diversification of education finance have become increasingly popular during the market transition (Loc, 2006; Chen \& Li, 2002; Ngok \& Kwong, 2003). Despite the ideological debates on whether education should be commercialized, the leaders in China and Vietnam have been pragmatic in allowing non-state sectors, including the private sector and the market, to provide education (Yang 1997; Mok, 2000; Pham \& Fry, 2002). As a result, education institutions at all levels are active in establishing collaborations with sectors from diverse backgrounds, involving the public and private sectors as well as overseas institutions. With the emergence of self-financing students and non-state education providers (including private and foreign providers), education in China and Vietnam has been undergoing the processes of diversification, marketization and privatization (Mok, 2000; Pham \& Fry, 2002; Borevskaya, 2003; London, 2003; Ngok \& Chan, 2003; IIE, 2005).

The next section will examine how the Chinese and Vietnamese governments have transformed the education sector by adopting far more pro-competition policy instruments in line with privatization and marketization strategies.

\section{Changes in Practices: privatization and marketization in education}

\section{The Shifting of Educational Costs onto Individual Households}

Despite the intentions to increase government investment in education, the introduction of the 'fee-paying' principle in the last two decades has significantly directed the way social policy/social welfare is managed in these transitional economies. Departing from the socialist model in which education was a free public service solely provided by the state, the governments in China and Vietnam have significantly reduced their financial contributions to education. In China, for 
example, the state financial support to higher education had actually declined from $93.5 \%$ in 1990 to $50 \%$ in 2002 (Chen, 2006). With the continual decline in the central government's allocations to education, educational financing and provision has heavily relied upon the financial abilities of local governments and individual contributions. Coinciding with 'multiple channels' in financing, the state describes the use of a mixed economy of welfare as a 'multiple-channel' (duoqudao) and 'multimethod' (duofangfa) approach to the provision of educational services during the 'primary state of socialism' (shehui zhuyi chuji jieduan), indicating a diffusion of responsibility from the state to society (Cheng, 1990; Mok, 1996). The introduction of a 'fee-paying' principle has significantly affected higher education financing in China. Early in the 1980s, the plan for charging students fees was regarded as 'ultra-plan', implying that the intake of these 'self-supporting' students was beyond the state plan (Cheng, 1996). But after the endorsement of a socialist market economy in the CCP's Fourteenth Congress, the State Education Commission officially approved institutions of higher education admitting up to $25 \%$ of students in the 'commissioned training' or 'fee-paying' categories in 1992. In 1993, 30 higher learning institutions were selected for a pilot study for a scheme known as 'merging the rails', whereby students were admitted either because of public examination scores or because they were willing and able to pay a fee though their scores were lower than what was formally required. In 1994, more institutions entered the scheme and the fee-charging principle was thus legitimized (Cheng, 1996). The structural change in the financing of education in China is more obvious in higher education. Before the 1990s, the number of fee-paying students was only a very tiny group but it has been increasing since the adoption of the 'user charge' principle. The percentage of fee-paying students in higher educational institutions in Shanghai increased from $7.5 \%$ in 1988 to $32.1 \%$ in 1994 , showing a huge jump in 'self-financing' students (Yuen \& Wakabayashi, 1996).

Now, all university students have to pay tuition fees and the user-pays principle has been made the foundation of Chinese education. According to a recent report, tuition fees in higher education have increased by a multiple of 24, jumping from an average fee of 200 yuan per student in 1986 to about 6000 yuan in 2006 (Zhu, 2005). Zhu Qingfang, a renowned sociologist who has been monitoring Chinese urban residents' consumption patterns, repeatedly reports the heavy financial burden for parents in financing children's education ( $\mathrm{Zhu}, 2005)$. More recently, at least one-third of the household consumption in urban China has been allocated to education, health insurance and housing. In 2004 alone, education expenditure constituted around $7.8 \%$ of the total expenditure of urban residents in China. Comparing the urban household educational expenditure of 2004 with that of 2000, it increased by $41 \%$, with an annual growth rate of $9 \%$ in the last few years (Zhu, 2005). From 1994 to 2004, Chinese urban residents paid around 2000 billion yuan to education ministries/departments at different levels (Zhu, 2005, p. 94). In urban Zhejiang, one of the most economically prosperous areas in China, per capita education expenditure in 2003 was around 802 yuan, 4.2 times that of 1995 or an increase of $8.6 \%$ when compared to the previous year (2002). Another study of education expenditure conducted by Zhejiang provincial government also suggests an ordinary urban household in the province had to spend around 10,398 yuan annually for children's education in 2005 (Dai, 2005). Using 2004 prices, one source even suggests a cumulative sum of fees being paid b y an ordinary Chinese student from kindergarten to university is around 14,000 yuan (Dai, 2005). One recent report even suggests that now a four-year bachelor's degree can carry a price tag of up to 60,000 yuan; this amount would take a farmer in some underdeveloped areas more than 30 years to generate ( $\mathrm{Li}, 2007)$. Therefore, a number of university presidents and educationalists in China criticize the government for denying its responsibility in educational financing and for not keeping its promise in its commitment to educational development (Mingpao, 8 March 2006).

In Vietnam, cost recovery has been implemented under the theme of 'socialization' of education. The term 'socialization' is directly translated from the Vietnamese term ' $x a$ hoi hoa', which has a meaning of mobilizing the whole society to make contributions to national education under state guidance (Bui et al, 1999, cited in Loc, 2006). Under this principle, the introduction of tuition fees has been justified for cost recovery. Like China, the policy of fee-charging was first introduced in the higher education sector in 1987 by allowing higher education institutions to admit fee-paying students in excess of the centrally planned quota. Thereafter, the number of feepaying students grew quickly. By 1999, the number of fee-paying students had grown four times 
larger than the number of regular students (Ngo, 2006, p. 230). As for the school sector, school fees was introduced in 1989 and were applied to students in grade four and five in primary schools and all students in secondary schools. In 1993, the government decided to waive the tuition fee for primary attendance, but instead it increased the charge for secondary school students. In addition to tuition fees, local governments also charge various compulsory payments, such as a registration fee, contributions to a school maintenance and renovation fund, contributions to school purchasing and so on (London, 2003, p. 153; Bélanger \& Liu, 2004, p. 27).

Since the introduction of the fee-charging policy, household expenditures on education have significantly increased in Vietnam (Bray, 1996). In the early 1990s, individual households were responsible for $67 \%$ and $72 \%$ of the costs of lower and upper secondary education respectively, while household sources accounted for around $50 \%$ of the costs of primary education. Nevertheless, the same figures in China were around $20 \%$ for secondary education and around $30 \%$ for primary education. These substantial contributions from individual households made household costs on education in Vietnam the second highest in South-East Asia after Cambodia (Bray, 2002; Bélanger \& Liu, 2004). Moreover, family expenditures on education have increased much more than those on other social services like health care and housing, hence adding tremendous financial pressures onto families for meeting children's education needs. According to the Vietnam Living Standard Surveys of 1992-93 and 1997-98 conducted by the World Bank, household expenditures on education increased from $2.7 \%$ of total household expenditures in 1993 to $6.4 \%$ in 1998 , a $141 \%$ growth within five years, whereas the proportion of household expenditure on health care and housing recorded a decrease during the same period (belanger $\&$ Liu, 2007). As a consequence, the poorest households had to spend around $60 \%$ of their non-food budget on a child in lower secondary school, while upper secondary education became unaffordable to these families because the cost had exceeded their non-food annual budget. Even for the richest households, $30 \%$ of their non-food budget had to be spent on education (Bélanger $\&$ Liu, 2004, p. 27). Despite the government's efforts to launch fee exemption schemes for children from families with difficult economic circumstances, the high tuition fees have remained as a major barrier discouraging children from poor families to attend schools (General Statistical Office, 2000).

\section{The Growing Importance of the 'Private Sector' in Education}

The growing prominence of the 'private sector' in education is another prominent feature captured in China's transitional economy. In late 1993, the Program for Reform and the Development of China's Education stipulated that the national policy was actively to encourage and support social institutions and citizens to establish schools according to the laws and to provide the right guidelines and strengthen administration (CCCCP, 1993). Article 25 of the Education Law promulgated in 1995 confirmed once again that the state would give full support to enterprises, social institutions, local communities and individuals to establish schools under the legal framework of the People's Republic of China (PRC) (SEC, 1995). In short, the state's attitude towards the development of non-state-run education can be summarized by the phrase 'active encouragement, strong support, proper guidelines, and sound management' (jiji guli, dali zhichi, zhengque yindao, jiaqiang guanli). Under such a legal framework, coupled with the 'decentralization' policy context, educational providers have proliferated, particularly when the Chinese state, in an effort to expand capacity, encouraged all democratic parties, social organizations, retired cadres and intellectuals, collective economic organizations and individuals subject to the Party and governmental policies, actively and voluntarily to contribute to developing education through various forms and methods (Wei \& Zhang, 1995, p. 5).

In 2005, Hu Jin, Head of the Department of Education Planning and Development of the Ministry of Education, People's Republic of China (MOE), reported on current developments of private/minban higher education at a press conference, indicating that by the end of 2004, there were 1.4 million students enrolled in these institutions, which accounted for $10.4 \%$ of the national total, representing an increase of $3.16 \%$. According to $\mathrm{Hu}$, approximately 1300 private/minban higher education institutions had developed by 2004, of which 228 have received official authorization to grant diplomas and 23 have been authorized to offer undergraduate degrees (China Education and Research Network, 2005). Another report suggests that of the 1260 private/ 
minban higher education institutions, 50 of them have become so-called 'wanren daxue', meaning that each of them has enrolled over 10,000 students (Lin, 2006). Officials from the MOE also project that future higher education expansion will take place through the private/minban sector (China Education and Research Network, 2005). Despite the fact that the private/minban higher education sector remains small when compared to the large public sector, the private share of enrolments has been spectacular in terms of the growth rate, especially when viewed in a socialist political context. Seen in this light, education provision has obviously been diversified in the post-Mao period, especially with the increase in the private sector and the popularity of these market initiatives in higher education governance (Lin et al., 2005; Mok, 2005; Levy, 2006).

More importantly, the rise of the private/minban sector in China's education has developed towards a hybrid of public and private. Two types of minban higher education, including secondtier colleges and transnational programmes jointly offered by Chinese and foreign partners, are typical examples of the public-private blurring. Second-tier colleges refer to the extension arm of public (national) universities, which are run as 'self-financing' entities and operated in terms of 'market' principles. Considering conventional minban colleges lacking 'self-discipline' and posing difficulties for management, such kinds of publicly-owned but privately-run higher education institutions are established as alternatives for achieving the policy objectives of increasing the higher education enrolment rate (Lin, 2004; Lin, et al, 2005; Shi et al, 2005). But, with their characteristics of fee-charging under the market mechanism, second-tier colleges also serve as revenue-generating projects with a background of decreasing government financial support. It is against this wider policy context that these sorts of 'quasi minban' institutions have become increasingly popular in China. By 2005, there were 344 second-tier colleges throughout China, enrolling 540,000 undergraduate students (Chen $\&$ Yu, 2005, p. 167).

After becoming a member of the WTO, China has also subscribed to the GATS agreement, thus permitting competition in the market of ideas and knowledge products and rationalizing the global trade in knowledge (Altbach, 2004). It is also against this policy environment that international public-private partnership of higher education has increased such as jointly offering academic programmes by local and foreign institutions in China (Huang, 2005). In 2003, the government issued the Regulations of the People's Republic of China on Chinese-Foreign Cooperation in Running Schools, providing details not only on how transnational higher education is governed but also allowing overseas institutions of higher learning to make a profit from these joint programmes (State Council, 2003). With a more favourable policy background, there were 745 joint programmes provided in Chinese institutions in collaboration with overseas partners in 2004. As the higher education sector in China is still dominated by the public sector in term of provision, most local providers are public universities, thereby representing a growing trend of private-public partnerships in higher education provision in China (MOE, 2006).

The emergence of private education in Vietnam began at pre-primary level in the 1990s. The Ministry of Education and Training's Decision No. 124 was to 'guide, manage, and encourage the foundation of self-financing preschool' (cited in London, 2003, p. 151). Later in 1993, the state in its Resolution 90 further introduced a set of rules to allow the establishment of 'non-public' schools, including 'semi-public' (ban cong) and 'people-founded' (dan lap) schools. According to available data, $5 \%$ of lower secondary students, $50 \%$ of kindergarten students, $34 \%$ of upper secondary students, and $11 \%$ of tertiary students studied in non-public schools in 2001 (Loc, 2006). Currently, non-public education institutions include three types, namely 'semi-public' (ban cong), which refers to those owned by the state but managed by public authorities at various levels and operated upon the cost from tuition fees; 'people-founded' (dan lap), which means that the institutions are owned and managed by non-government organizations or private associations and operated upon the cost from tuition fees; and 'private' ( $t u$ lap), which are owned and managed by private individuals (IIE, 2005, p. 8).

As for the higher education sector, Thang Long University is the first non-public university in Vietnam and was established as an experiment in 1988. Although the operation of the University met many difficulties, its establishment represents the beginning of privatization, marketization and commercialization of higher education in Vietnam. After the experiment of Thang Long University, a number of non-public universities have been established (Hoang \& Sloper, 1995; Pham \& Fry, 2002). At present, non-public education occupies a significant proportion in higher 
education sector. In 2004, there were 137,122 students enrolled in non-public institutions, which accounted for $15.3 \%$ of the national total. In terms of the number of institutions, there were 224 higher education institutions, among which 24 were non-public institutions, of which 7 were semipublic and 17 people-founded (Ngo, 2006, p. 243). According to the Higher Education Reform Agenda (HERA) issued by the Ministry of Education and Training (MOET), the non-public higher education sector should further expand in order to enrol $40 \%$ of the total number of tertiary students by 2020 (Hayden \& Lam, 2007, p. 79).

In addition, the Vietnamese government has started to open the door to outside education providers. As discussed earlier, rejoining the regional and international market is critically important for the development of transnational education in Vietnam. For instance, Vietnam reestablished normal diplomatic relations with the USA in 1997. Thereafter, bilateral trade between the two countries has continuously grown. Today, the USA is one of Vietnam's largest trading partners and English becomes increasingly important in the country. In many universities, English is the most popular choice for students in their choice of foreign language learning. Meanwhile, privately run language schools have become popular throughout the country and a number of overseas investors have actively started and run English-language institutes to meet the pressing needs for learning English (Overland, 2006). Indeed, foreign education programmes run either by foreign institutions or through cooperation between overseas and local institutions have been expanding quickly. For example, the University of Hawaii provides an MBA programme in partnership with Hanoi School of Business; Washington State University provides an MBA programme with the National Economics University; University of Houston, Clear Lake offers undergraduate degrees with the Hanoi University of Technology; Troy State University offers undergraduate degrees in collaboration with the International College of Information Technology and Management (IIE, 2005, p. 18). The establishment of the Royal Melbourne Institute of Technology in 2001 was a milestone of the emergence of the private and foreign sector in education. The Institute is the first wholly foreign-owned degree-awarding institution in Vietnam. Its programmes include information technology, engineering and business (Overland, 2006). Recognizing the proliferation of foreign education, the Vietnamese government promulgated Decree No. 06/2000/ND-CP in 2000 in order to provide a regulatory framework and also incentive for foreign investment in education and training, whereas in 2001 the government has regulated the entry of foreign education programmes into the local market by requiring that only those existing institutions with licences in their home countries can apply to launch programmes in Vietnam (IIE, 2005, p. 18). After joining the WTO, the Vietnamese government has begun to change its laws allowing overseas institutions to run education for profit notwithstanding the unfinished debates on the nature of education as a public or private good. It is against this new policy context that more for-profit education institutions have emerged in Vietnam to offer transnational education programmes (Pham, 2006; Ashwill, 2006).

Up to this point, we have discussed how education has been privatized and marketized in China and Vietnam. Such transformations are not without problems, especially when we critically examine the social and political consequences of these changes during the market transition in China and Vietnam. The rapid growth in education has resulted in problems of quality assurance, while the reliance upon market forces in meeting people's educational needs has also intensified the inequalities in education in these Asian economies. Let us now turn to examine the major challenges resulting from the privatization and marketization of education in China and Vietnam.

\section{Challenges for Privitizing/Marketizing Education}

\section{Unresolved Debates on the Private and Public Nature of Education}

Despite the fact that the Chinese and Vietnamese governments have joined the WTO and have tried to honour their commitments in following the principles of GATS, we have witnessed unresolved debates on the public and private nature of education. Comparing the development of private education in China with that of Vietnam, we can argue that China has been at a more advanced stage of development, especially when private/minban education has evolved since the mid-1980s (Mok, 2000; Mok \& Ngok, 2008). It is particularly true when comparing the legal foundation for private education in these countries, which has shown that China has a more 
established foundation for private/minban education. For example, the Law of the People's Republic of China on Promotion of Privately-Run Schools promulgated in 2002 has provided a legal framework on private education in China. The breakthrough in the document is that of allowing education investors to make profit through provision of private/minban education. In addition, as mentioned earlier, the Regulations of the People's Republic of China on Chinese-Foreign Cooperation in Running Schools promulgated in 2003 also gives the green light to profit-making in the collaboration between local and foreign institutions. Nonetheless, our recent research on private/ minban education in China has indicated that the education market in China is a 'governed market', whereby it is highly regulated by the state. The growing prominence of second-tier/affiliated colleges run on a self-financing principle has shown how the Chinese government has attempted to create its own education market to constrain the development of the conventional private/minban education institutions because the Ministry of Education has the final decisions regarding the academic qualifications of the programmes offered by the conventional private/minban institutions, as well as determining the profit level for the private/minban colleges (Mok \& Ngok, 2008).

In contrast, even though the Education Law published in Vietnam in 2005 has provided a general legal basis for the governance of the non-public education sector, it did not end the debate on the profit-making issues in education. Article 66 of the document states that schools/educational institutions run by social organizations and private education institutions have financial autonomy and allows the investors to divide the profits according to their capital contribution, whereas Article 20 states that 'making use of education activities for profit is forbidden' (citied in Hayden $\&$ Lam, 2007, p. 77). Indeed, practically, investors in private education institutions in Vietnam might keep the profit, while technically their investment is considered as a donation to the public good because non-public universities also belong to 'the people'. This becomes a factor restricting private investment in education in Vietnam (Overland, 2006a). Despite the fact that the MOET has recently issued two provisional regulations on governing non-public education, the relevant legal framework is criticized as 'not yet well-developed' and private universities are run without transparency and accountability (Ngoc \& Ashwill, 2004; Ngo, 2006). Yet, it is recognized that previously the responsibilities of individual institutions and their relationship with the state were defined on a case-by-case basis. The ambiguity of the situation provides space for individual institutions to exercise autonomy (Ngo, 2006). Perhaps, the Vietnamese authorities intend to reserve the grey areas in order to provide more space for the survival of private education institutions, as many of them claim that they are operating in an extremely difficult situation (Overland, 2006). Although the Vietnamese government has recently amended its laws to allow institutions to run for-profit education, the debates on whether education is a public or private good have not ended in Vietnam especially when the government has seen the education market as only a quasi-market. Putting these observations together, although there have been newly enacted laws governing private education in China and Vietnam the actual implementation of the policies has shown the unresolved tensions between whether institutions could make profits for running education and the unfinished ideological debates on whether education is a public or private good.

\section{The Unresolved Dilemma between Quantitative Growth and Quality Assurance}

The rapid expansion of education by privatization and marketization strategies has raised concerns for quality assurance. It is beyond doubt that both China and Vietnam have experienced great economic success through the adoption of market reforms and continuous integration with the global economy. For example, China recorded double-digit economic growth (estimated at 10.7\%) in 2006, while Vietnam also achieved a high GDP growth rate (estimated at $8.2 \%$ ) (CIA, 2007). The economic growth has generated an increase of both public and private expenditure on education, especially when education is seen as a sort of investment on human capital (Organization for Economic Cooperation and Development [OECD], 1998), which has been shown by the growth of enrolment rate at various levels in these two countries (UNESCO Institutes for Statistics, 2007). Despite the growth in quantity, there have been concerns raised about the assurance of educational quality. For example, the number of university students rose 3.96 times from 1993 to 2002 but the number of teachers only rose only 1.47 times in Vietnam during the same period. This makes the ratio of teachers to students 1:29, one of the highest in the world, indicating an insufficient supply 
of teachers catering for the increase in student enrolments (Pham \& Fry, 2002, p. 138). In addition to the shortage of teaching staff, the qualifications for teaching are concerned. Despite the fact that English is becoming more popular and commonly taught in Vietnam's universities now, many university teachers do not speak the language but are forced to adopt English as a medium of instruction (Overland, 2006). Similarly in China, many minban education institutions tend to employ more part-time and retired faculty members and therefore it is difficult to assure the quality of teaching. This is particularly true because there is not yet a well-developed quality assurance system of teaching in China (Chan, 2007).

Nevertheless, if we look at the top tier part of the education sectors, we can recognize the differences between the two countries. In China, the government has shown its intention of building world-class universities and offers generous financial support to those selected institutions. For example, from 1996 to 2000, more than 10 billion yuan was invested in 99 universities under the ' 211 project' and the two key universities, Peking University and Tsinghua University, were granted 1.8 billion yuan of extra budget under the '985 scheme' in 1999 (Ngok \& Guo, 2007, p. 31). These have substantially shown China's ambition of and commitment to developing world-class universities in the country. In Vietnam, two national universities, namely Vietnam Nation University in Hanoi and Vietnam Nation University in Ho Chi Minh City, are granted ministeriallevel status and significant financial and administrative autonomy from the MOET (Hayden \& Lam, 2007). We can expect that their leading role is similar to that of Peking University and Tsinghua University in China in order to build a top-tier international university in Vietnam. In addition, Vietnam has recently started to establish collaborations with other countries, such as Singapore and the USA, on education (Cathcart, 2006; The Straits Times, 26 April 2007). However, according to a recent article published in the Chronicle of Higher Education, Vietnam's higher education system is ' 20 , even 30 years, out of date ... the country does not have a single university considered to be international quality. It lacks a credible research environment, produces few $\mathrm{PhDs}$ and is locked in Soviet-style pedagogy' (Overland, 2006, p. 37). Indeed, when we recognize that the Royal Melbourne Institute of Technology, the only foreign-owned university in Vietnam, is requested to teach Ho Chi Minh thought and 'Scientific Socialism' but the University of Nottingham Ningbo China adopts programmes entirely the same as those in the United Kingdom, we might be able to identify the differences between the two countries in terms of their levels of internationalization and academic standards (Overland, 2006; University of Nottingham Ningbo China, 2007).

\section{Unresolved Tensions between Efficiency and Equality in Education}

Making use of market forces in education has brought improvements to education in China and Vietnam. By examining the recent statistics regarding the improved literary level and enrolment rate of these socialist countries, UNESCO has recently remarked that China and Vietnam have made significant achievements in raising education standards, with schools achieving universal education, and higher education developing toward mass education (UNESCO Institutes for Statistics, 2007). However, these achievements are not evenly shared among different social groups and geographical regions in these Asian economies. Unsurprisingly, rich households and regions enjoy larger improvements than poor households and regions do, hence widening social inequalities in these two socialist counties. Indeed, inequality between rich and poor as well as urban and rural has become one of the most challenging problems in the growing prominence of the private sector in China's education (Mok \& Lo, 2007).

Realizing that educational inequalities have become intensified, both the Chinese and Vietnamese governments recognize the importance of providing basic education to the citizens, hence, the school education sector has attracted relatively more state funding than that of higher education. In China, with a continual increase in state funding to elementary education in recent years, the net enrolment rate of primary school children grew to $99 \%$ in 2005 , while the gross enrolment rate of junior secondary schools reached 95\% (China Education and Research Network, 2005). Since the promulgation of the Compulsory Education Law in 1986, nine-year compulsory education has been implemented. Given that primary and secondary education has been universalized in many urban areas and economically developed coastal areas, the Chinese 
government has allocated extra resources to create more educational opportunities in rural areas during the Tenth Five Year Plan (2001-2005). In late 2005, the State Council decided to further reform the funding system of school education in rural areas, with nine-year compulsory education funded by the general public finances (China Education and Research Network, 2005). Among the various tasks in the Eleventh Five Year Plan (2006-2010), the consolidation of nine-year compulsory education in rural areas has been given high priority, with the implementation of the 'Two Basics' project to universalize nine-year compulsory education and to eradicate illiteracy among the middle and young aged groups in the western part of China. Regarding educational finances, the government decided to waive all the tuition and miscellaneous fees of students from rural areas of western China in 2006 in order to release parents from the heavy burden of educational expenses. The same policy was introduced to the central and eastern parts of the country in 2007 (China Education and Research Network, 2005). However, it is realized that those disadvantaged groups such as new urban immigrants in China are still being neglected and discriminated against in the current education system. Being regarded as temporary immigrants or 'floating population', these new urban immigrants cannot obtain the same social status as their urban counterparts because they are still classified as rural citizens without an urban hokou registration. Although some local schools in cities accept these temporary migrant children, their parents have to pay for the education endorsement fee (jiaoyu zanzhu fei), which is considerably high (Cao, 1997).

In Vietnam, the government has addressed the increasing burden of higher education financing that parents and individuals have experienced since 1989. In response to the high fee problems, the government has introduced several national programmes to exempt poor households from paying tuition fees. Eligibility was based on a poverty line set by the state. But, the programmes were less than effective owing to the extremely harsh conditions in poor rural areas. Therefore, the government has turned to poverty reduction in order to narrow the regional disparity. In 1993, the Ministry of Labour, Invalids, and Social Affairs (MOLISA) set national poverty lines in aid of the poor communities and households. During the Eighth Party Congress in 1996, the Vietnamese authorities decided to secure free access to basic education for the poorest people by including this policy into the outline of objectives of hunger eradication and poverty reduction. The programmes aim to erase illiteracy by exempting or reducing school fees as well as providing grants and scholarships to students from poor rural families. As reported in 1999, the MOET had committed over 834 billion dong over three years, an amount equal to about $2 \%$ of the annual education budget during the period. By the end of 1998, the government had established 6958 hunger eradication and poverty reduction boards at commune level in order to ensure that local authorities would follow the criteria set by the central government in mapping the poorest households. However, these programmes only benefited those families who fell into the lowincome group. Moreover, the poverty line was criticized as being set too low. Moreover, the exemption can partially help students from poor families only. Their families still need to bear other expenditures on education, such as living costs, transport and so on, which are a heavy burden to those families in harsh living conditions (London, 2003, pp. 166-168). Indeed, although the enrolment rate has significantly increased in the last decade, the drop-out rate is also alarming. A study on schooling in Vietnam indicates that the higher cost of secondary education compared to primary education is one of the reasons for explaining the considerably high drop-out rate. The study also points out that dropping out as an interruption to schooling would seriously jeopardize the progression from primary education to lower secondary education (Bélanger \& Liu, 2004, pp. 36-37). In short, despite the effort by the central government in China and Vietnam, inequality of access to education is still a significant problem in the two countries.

Furthermore, if we look at the issue of educational inequality within the context of cultural values, the influence of the traditional Confucianism with its emphasis on learning and stressing the importance of a willingness to exert effort to master schoolwork (Cummings, 1996) has widened the gap between the rich and the poor. The positive impact of such a traditional value has certainly reinforced people to look for better education and created a conducive environment for the rise of private education. Nonetheless, the same cultural values would also disadvantage those who are unable to pay for private education, especially when increasing pressure is placed on parents to give their children the best education despite the overwhelming financial burdens. For wealthy families, they are free to send their children to after-school classes and activities without financial 
constraints. However, it is very difficult for families from relatively poor socio-economic backgrounds to pay a few thousand yuan in China or a few hundred US dollars in Vietnam per year on after-school education for their children. Given that results of these extracurricular activities would increasingly affect the formal education of children as well as their career development, I suggest that the prominence of after-school education, as a sort of commercialization of education, has made the whole education system more competitive. More sociologically important, this is a problem about how to address the contradictions between rapid economic growth and the intensified social inequality/regional disparity. From a political perspective, it is about the ideological dilemma between socialism and capitalism. How to resolve the unresolved tensions between educational efficiency and equality is becoming an increasingly important political challenge confronting both the Chinese and Vietnamese governments.

\section{Conclusion: bringing the 'public' back in education?}

Our discussion has shown that the communist authorities in China and Vietnam have recognized the importance of being committed to developing education in the knowledge-based economy. Nonetheless, government investment on education only occupied $2.3 \%$ of GNP in China, while the figure in Vietnam was $2.7 \%$ in the mid 1990s. Such state investments in education were considerately low when compared to the average investment rate of other countries in East Asia $(3 \%)$ or other less developed regions such as in Africa (5.6\%), Latin America (4.5\%) and South Asia (4.3\%). Nevertheless, observers forecasted that the proportion would be raised in China (Bray, 2002, pp. 6-8). Realizing the low level of the state's educational investment, the State Council of the People's Republic of China has most recently decided to increase government funding to education. It is against this context that the Eleventh Five Year Programme Guidelines on Education (2006-2010) calls on governments at all levels to make the development of education a strategic priority and 'to commit to a public education system that can be accessed by all' (cited in $\mathrm{Li}, 2007)$. Conversely, despite the fact that the Vietnamese government has shown its intention to further develop education, it charges substantially more for educational services and this has led to an open debate in the National Assembly and the media (Luong, 2006, p. 151).

In addition, we have discussed how both the Chinese and Vietnamese governments have introduced new policy measures to help citizens who come from lower socio-economic background to get access to education; the success of these new policies depends heavily upon how the local governments have genuinely implemented the policies issued by the central government. In China, the attempts to de-privatize and de-marketize education governance reflect the Hu-Wen administration's determination to rectify the mistakes resulting from the quest for 'GDPism'. But whether the senior Chinese leaders would have the capacity to implement the proposed changes and turn the heavily market-driven social policy paradigm deeply embedded in the post-Mao era into a more humanistic approach is still subject to question. In this connection, de-privatization and de-marketization is less a matter of reversal-cum-reconstruction in the context of new thinking about the limits to privatization and marketization strategies, but more an exercise in 'damage control' by which private and para-state organizations operating in the market are subject to new forms of regulation and some direct measures of subsidy are introduced to address the plight of the very poor However, heightened public investment in the rural and non-coastal areas is introducing a potentially contradictory 'dual-track' system in which marketization may only be delayed: the incentives and legal framework for marketization will probably see the private sector grow in these parts of the country, just as it did in the coastal regions, as more funds are injected into the system (Painter \& Mok, 2007).

Similarly, the attempts to reduce the pace of the marketization of education in Vietnam have not been able to stop the momentum, especially after Vietnam has entered the WTO. With the increase of the involvement of overseas partners, the education market has expanded rather than contracted. In this regard, I would argue the fundamentals have not significantly altered even when both governments have taken initiatives to reverse the privatization and marketization in education. We should not underestimate the tensions between different levels of governments, with a diversity of stakeholders competing for their vested interests in a privatized and marketized education context. It is clear that the present Chinese and Vietnamese authorities have tried to 
address the tensions and contradictions between rapid economic growth and worsening social inequalities. However, in the case of education, we have argued that any attempted reversal from the market-driven approach to a more state-centred, welfare-based approach would exceed the capacities of the state. Tensions and contradictions in education policy provide just one case among many others in contemporary China and Vietnam of a core political dilemma: how to uphold socialist ideologies in a neo-liberal policy setting, in order to preserve the legitimacy of the ruling political parties.

\section{References}

Altbach, P.G. (2004) Globalisation and the University: myths and realities in an unequal world, Tertiary Education and Management, 10, 3-25. http:/ / dx.doi.org/10.1023/B:TEAM.0000012239.55136.4b

Ashwill, M.A. (2006) US Institutions and Fertile Ground in Vietnam's Expanding Higher Education Market. Paper presented at the International Forum on 'WTO Entry and Vietnam Higher Education Reform', Hanoi, Vietnam, 11-12 December.

Banh, T.L. (2006) State Management Reform for Vietnam Higher Education. Paper presented at the International Forum on 'WTO Entry and Vietnam Higher Education Reform', Hanoi, Vietnam, 11-12 December.

Bélanger, D. \& Liu, J. (2004) Social Policy Reforms and Daughters' Schooling in Vietnam, International Journal of Educational Development, 24, 23-38. http: / / dx.doi.org/10.1016/j.ijedudev.2003.08.001

Borevskaya, N. (2003) The Private Sector in the Chinese Educational System: problem and prospects, Far Eastern Affairs, 31(4), 89-107.

Bray, M. (1996) Counting the Full Cost: parental and community financing of education in East Asia. Washington, DC: The World Bank.

Bray, M. (2002) The Costs and Financing of Education: trends and policy implications. Manila and Hong Kong: Asian Development Bank and Comparative Education Research Centre, University of Hong Kong.

Cai, B.K. (2005) China's Peaceful Development and Relations with East Asian Neighbours, in S.H. Saw, L. Sheng \& K.W. Chin (Eds) ASEAN-China Relations: realities and prospects. Singapore: Institute of Southeast Asian Studies.

Cao, H. (1997) Where to Put their School Desks? China New Digest, 315, 3-6.

Cathcart, M. (2006) Asia’s Possibilities, Connection, Fall, 13.

Central Committee of the Chinese Communist Party (CCCCP) (1985) The Decision of the Central Committee of the Communist Party of China on the Reform of Educational Structure. Beijing: People's Press.

Central Committee of the Chinese Communist Party (CCCCP) (1993) The Programme for Educational Reform and Development in China, Zhonghua Renmin Gongheguo Guowuyuan Gongbao, 2, 58-66.

Central Intelligence Agency, USA (CIA) (2007) The World Factbook. https: / / www.cia.gov/library/publications/the-world-factbook/index.html

Chan, D. (2007) The Impact of Globalization on the Educational Developments in China: policy and challenges, in J.Y.S. Cheng (Ed.) Challenges and Policy Programmes of China's New Leadership. Hong Kong: City University of Hong Kong Press.

Chen, B. \& Li, G. (2002) Minban gaodeng jiaoyu ziketiqu yanjiu baogao [The research report on people-run higher education], in B. Chen \& G. Li (Eds) Minban Jiaoyu de Gaige yu Fazhan [Minban reform and development of people-run education]. Beijing: Jiaoyu Kexue Chubanshe.

Chen, C.G \& Yu, Q.Y. (2005) Zoujin Dazhonghua: 21 Shijichu Guangzhou Shi Gaodeng Jiaoyu Fazhan Yanjiu [Towards massification: research on Guangzhou's higher education development in early 21st century]. Guangzhou: Jinan daxue chubanshe.

Chen, X. (2006) High-Risk Enterprises: will universities go bankrupt? http: / / www.dajun.com.cn/ daxuepc.htm

Cheng, K.M. (1990) Financing Education in Mainland China: what are the real problems? Issues and Studies, 3 , 54-75.

Cheng, K.M. (1995) Education - decentralization and the market, in L. Wong \& S. MacPherson (Eds) Social Change and Social Policy in Contemporary China. Aldershot: Avebury.

Cheng, K.M. (1996) Markets in a Socialist System: reform of higher education, in K. Watson, S. Modgil \& C. Modgil (Eds) Educational Dilemmas: debate and diversity. London: Cassell.

China Education and Research Network (2005) http: / www.edu.cn/20050301/3129836.shtml 
Cook, S. (2002) From Rice Bowl to Safety Net: insecurity and social protection during China’s transition, Development Policy Review, 20(5), 615-635. http:/ / dx.doi.org/10.1111/1467-7679.00192

Cummings, W. (1996) Asian Values, Education and Development, Compare, 26(3), 287-304. http: / / dx.doi.org/ 10.1080/0305792960260304

Dai, J.L. (2005) Resident's Life: moving towards the society of overall well-to-do level, in B. Ren (Ed.) 2005 Blue Book of Zhejiang. Hangzhou: Hangzhou Publishing House.

General Statistical Office (2000) Viet Nam Living Standards Survey 1997-1998. Hanoi: Statistical Publishing House.

Guan, X.P. (2001) China's Social Policy in the Context of Globalization, in Social Policy Research Centre, Hong Kong Polytechnic University (Ed.) Repositioning of the State: challenges and experiences of social policy in the Asia Pacific region. Hong Kong: Joint Publishing Co.

Hawkins, J.N. (2000) Centralization, Decentralization, Recentralization: educational reform in China, Journal of Educational Administration, 38(5), 442-454. http: / / dx.doi.org/10.1108/09578230010378340

Hayden, M. \& Lam, Q.T. (2007) Institutional Autonomy for Higher Education in Vietnam, Higher Education Research \& Development, 26(1), 73-85. http: / / dx.doi.org/10.1080/07294360601166828

Hoang, X.S. \& Sloper, D. (1995) An Entrepreneurial Development: Thang Long University, in D. Sloper (Ed.) Higher Education in Vietnam: change and response. New York: St Martin’s Press.

Huang, F.T. (2005) Qualitative Enhancement and Quantitative Growth: changes and trends of China's higher education, Higher Education Policy, 18, 117-130. http:/ / dx.doi.org/10.1057/ palgrave.hep.8300076

Institute of International Education (IIE) (2005) Higher Education in Vietnam Update - May 2004. Hanoi: Institute of International Education.

Levy, D. (2006) New Private Realities in Chinese Higher Education. http: / www.albany.edu/dept/eaps/prophe/publication/News/SummaryAsia

Li, R. (2007) Casualties of the Rush to Profit from Schooling, South China Morning Post, 27 January 2007.

Lin, J. (2004) China: private trends, International Higher Education, 36, 17-18.

Lin, J. (2006) Private Universities in China: expansion and challenges. Paper presented at the American Asian Studies Annual Meeting, San Francisco, 6-9 April.

Lin, J., Zhang, Y., Gao, L. \& Liu, Y. (2005) Trust, Ownership, and Autonomy: challenges facing private higher education in China, The China Review, 5(1), 61-82.

Liu, X.C. (2005) Strengthening ASEAN-China Cooperation in the ASEAN Regional Forum, in S.H. Saw, L. Sheng \& K.W. Chin (Eds) ASEAN-China Relations: realities and prospects. Singapore: Institute of Southeast Asian Studies.

Loc, N. (2006) Viet Nam's Education in the Transitional Period. http://www.apecknowledgebank.org/resources/downloads/06_hrdwg1_057.pdf

London, J.D. (2003) Vietnam's Mass Education and Health Systems: a regimes perspective, American Asian Review, 21(2), 125-158.

Luong, H.V. (2006) Vietnam in 2005: economic momentum and stronger state-society dialogue, Asian Survey, 46(1), 148-154. http:/ / dx.doi.org/10.1525/as.2006.46.1.148

Ministry of Education, China (MOE) (2006) List of Chinese-Foreign Cooperation in Running Schools Programmes. http://www.jsj.edu.cn/mingdan/002.html

Mok, K.H. (1996) Marketization and Decentralization: development of education and paradigm shift in social policy, Hong Kong Public Administration, 5(1), 35-56.

Mok, K.H. (2000) Marketizing Higher Education in Post-Mao China, International Journal of Educational Development, 20, 109-126. http: / / dx.doi.org/10.1016/S0738-0593(99)00062-0

Mok, K.H. (2005) Riding over Socialism and Global Capitalism: changing education governance and social policy paradigms in post-Mao China, Comparative Education, 41(2), 217-242. http:/ / dx.doi.org/10.1080/03050060500036956

Mok, K.H. \& Lo, Y.W. (2007) The Impact of Neo-liberalism on China's Higher Education, Journal for Critical Education Policy Studies, 5(1). http://www.jceps.com/index.php?pageID=article\&articleID=93

Mok, K.H. \& Ngok, K.L. (2008) One Country, Diverse Systems: politics of educational decentralization and challenges for regulatory state in post-Mao China, China Review, 8(2), 169-199.

Ngo, D.D. (2006) Viet Nam, in Higher Education in South-East Asia. Bangkok: UNESCO Asia and Pacific Regional Bureau for Education. 
Ngoc, M.L. \& Ashwill, M.A. (2004) A Look at Non-Public Higher Education in Vietnam, International Higher Education, 36, 16-17.

Ngok, K.L. \& Chan, K.K.D. (2003) Towards Centralization and Decentralization in Educational Development in China: the case of Shanghai, in K.H. Mok (Ed.) Centralization and Decentralization: educational reforms and changing governance in Chinese societies. Hong Kong: Comparative Education Research Centre, University of Hong Kong.

Ngok, K.L. \& Guo, W.Q. (2007) The Quest for World Class Universities in China: critical reflections, Journal of Comparative Asian Development, 6(1), 21-44.

Ngok, K.L. \& Kwong, J. (2003) Globalization and Educational Restructuring in China, in K.H. Mok \& A. Welch (Eds) Globalization and Educational Restructuring in the Asia Pacific Region. Basingstoke: Palgrave Macmillan.

Nguyen, D.Q. \& Sloper, D. (1995) Socio-Economic Background of Vietnam since 1986: impact on education and higher education, in D. Sloper (Ed.) Higher Education in Vietnam: change and response. New York: St Martin's Press.

Organisation for Economic Cooperation and Development (OECD) (1998) Human Capital Investment: an international comparison. Paris: Centre for Education Research and Innovation, Organisation for Economic Cooperation and Development.

Overland, M.A. (2006) Higher Education Lags behind the Times in Vietnam: outdated thinking in the classroom hampers the country's reform efforts, Chronicle of Higher Education, 52(4), 37.

Painter, M. \& Mok, K.H. (2007) Reasserting the Public in Public Service Delivery in China: the deprivatization and de-marketization of education? Paper presented at the International Conference on the Role of the State in Public Service Delivery, Lee Kuan Yee School of Public Policy, National University of Singapore, Singapore, 27-28 September.

Pham, D.N.T. (2006) WTO/GATS Implications and Vietnam Higher Education Development. Paper presented at the International Forum on 'WTO Entry and Vietnam Higher Education Reform', Hanoi, Vietnam, 11-12 December.

Pham, L.H. \& Fry, G.W. (2002) The Emergence of Private Higher Education in Vietnam: challenges and opportunities, Education Research for Policy and Practice, 1, 127-141. http: / / dx.doi.org/10.1023 / A:1021130320485

Saich, T. (2004) Politics and Governance in China. Basingstoke: Macmillan.

Shi, Q.H., Wu, M., You, S. \& Liu, W. (2005) Affiliated Colleges and Private Education Development in China: take independent colleges as an example. http:/ / www.ocair.org/files/presentations/Paper2003_04/forum2004/ChinaHE.pdf

So, A. (2003) Introduction: Rethinking the Chinese Developmental Miracle, in A. So (Ed.) China's Developmental Miracle: origins, transformations, and challenges. Armonk, NY: M.E. Sharpe.

State Council (2003) Regulations of the People's Republic of China on Chinese-Foreign Cooperation in Running Schools. Beijing: State Council.

State Education Commission (SEC) (1995) Education Law. Beijing: State Education Commission.

UNESCO Institutes for Statistics (2007) Data Centre.

http: / / stats.uis.unesco.org/unesco/TableViewer/document.aspx?ReportId=143\&IF_Language=eng

University of Nottingham Ningbo China (2007) http:/ / www.nottingham.edu.cn/index.php

Wei, Y.T. \& Zhang, G.C. (1995) A Historical Perspective on Non-governmental Higher Education in China. Paper presented to the International Conference on Private Education in Asia and the Pacific Region, University of Xiamen, Xiamen.

Wong, L. \& Flynn, N. (Eds) (2001) The Market in Chinese Social Policy. Basingstoke: Palgrave.

Wong, L., White, L. \& Gui, X.S. (2004) Social Policy Reform in Hong Kong and Shanghai. Armonk, NY: M.E. Sharpe.

Yang, R. (1997) The Debate on Private Higher Education Development in China, International Higher Education, Fall, 1-4.

Yang, R. (2002) The Third Delight: internationalization of higher education in China. London: Routledge.

Yuen, Z.G. \& Wakabayashi, M. (1996) Chinese Higher Education Reform from the 'State Model' to the 'Social Model': based on a Sino-Japan comparative perspective, Forum of International Development Studies, 6, 173-200.

Zhu, Q.F. (2005) Social and Economic Indicators: analysis and assessment, in X.Yu, P.L. Li \& X.Z. Lu (Eds) Analysis and Forecast on China's Social Development 2006. Beijing: Social Sciences Academic Press. 
KA HO MOK is Associate Dean and Professor, Faculty of Social Sciences, University of Hong Kong, and he has researched and published extensively in comparative education policy with focus on Asia. He is also President of Hong Kong Educational Research Association and Board Member of Asia-Pacific Education Research Association.

Correspondence: Professor Ka Ho Mok, Faculty of Social Sciences, The University of Hong Kong, Pokfulam Road, Hong Kong (ka-ho.mok@hku.hk). 